\title{
PENGARUH PENERAPAN SISTEM MANAJEMEN KEAMANAN PANGAN ISO 22000:2005 TERHADAP KUALITAS PRODUK PANGAN PADA DEPARTEMEN PRODUKSI NOODLE PT. JAKARANA TAMA FOOD INDUSTRY (FACTORY) BOGOR
}

\author{
Selviana Ernayanti Aprilia ${ }^{1)}$ Samsuri $^{2)}$,Titiek Tjahja Andari ${ }^{3)}$ \\ Program Studi Manajemen, Fakultas Ekonomi, Universitas Djuanda Bogor \\ Email:selviana.aprilia21@gmail.com,samsuri.lido@gmail.com, titiek.tjahja@gmail.com \\ Correspondence author : samsuri.lido@gmail.com
}

\begin{abstract}
The purpose of the research is to determine the effect of application food safety management system ISO 22000:2005 to food quality in noodle production departement PT. Jakarana Tama Food Industry (Factory) Bogor. Questioner distributed 100 respondents. Analysis method used is descriptive analysis and verification. The questioner validity and reliability testing and test the classic assumption. Likert scale is used prior to testing with multiple regressions. In order to know the effect of four free variable that is used for dependent variable. Based on the result all indicators expressed validity and reliability, simultaneously with interactive communication $\left(X_{1}\right)$, system management $\left(X_{2}\right)$, prerequisite programmes $\left(X_{3}\right)$ and HACCP principles $\left(X_{4}\right)$ have an influence to food quality in noodle production departement PT. Jakarana Tama Food Industry (Factory) Bogor (Y). Partially, only a few prerequisite programmes that gives positive and significant to food quality in noodle production departement.
\end{abstract}

Keywords: Brand Image, Quality Product, Purchasing Decisions

\begin{abstract}
ABSTRAK
Penelitian ini bertujuan untuk mengetahui pengaruh penerapan Sistem Manajemen Keamanan Pangan ISO 22000:2005 terhadap kualitas produk pangan pada departemen produksi noodle PT. Jakarana Tama Food Industry(Factory) Bogor. Kuesioner dibagikan kepada 100 orang responden. Metode analisis yang digunakan adalah metode survey, bentuk penelitian yaitu deskriftif dan verifikatif. Kuesioner tersebut menggunakan uji validitas, reliabilitas, asumsi klasik. Skala likert digunakan sebelum dilakukan pengujian dengan regresi berganda. Hal ini untuk mengetahui pengaruh empat variabel bebas yang digunakan terhadap satu variabel terikat. Hasil penelitian ini berdasarkan hasil uji validitas dan reliabilitas menunjukkan bahwa semua indikator dinyatakan valid dan reliabel secara simultan komunikasi interaktif $\left(\mathrm{X}_{1}\right)$, manajemen sistem $\left(\mathrm{X}_{2}\right)$, program persyaratan dasar $\left(\mathrm{X}_{3}\right)$, dan prinsip $\mathrm{HACCP}\left(\mathrm{X}_{4}\right)$, berpengaruh terhadap kualitas produk pangan pada departemen produksi noodle PT. Jakarana Tama Food Industry(Factory) Bogor (Y). Sedangkan secara parsial hanya indikator program persyaratan dasar yang mempengaruhi kualitas produk pangan pada departemen produksi noodle PT. Jakarana Tama Food Industry(Factorv) Bogor.
\end{abstract}

Kata Kunci: Sistem Manajemen Keamanan Pangan ISO 22000:2005, Kualitas Produk Pangan 


\section{PENDAHULUAN}

Pesatnya kemajuan industri sekarang ini mengakibatkan kompetisi yang semakin ketat di semua bidang, contohnya seperti bidang pangan, dimana terjadi perkembangan sistem penjaminan kualitas produk yang diperoleh oleh produsen industri pangan. Perkembangan sistem ini mengakibatkan adanya kompetisi antar industri, industri pangan bersaing dalam penjaminan kualitas dan keamanan produk pangan yang dihasilkan. Hal tersebut dimaksudkan supaya industri pangan dapat bertahan dan berkembang.

Pelaksanaan keamanan pangan ISO 22000 pada industri pangan adalah bagian dari usaha perusahaan dalam peningkatan dan penjaminan kualitas produk. Pelaksanaan keamanan pangan ISO 22000:2005 dilakukan pada seluruh produsen yang menghasilkan produk pangan dari produsen hilir hingga konsumsi akhir, tujuannya supaya konsumen memperoleh hak dalam mengkonsumsi produkyang jauh dari bahaya serta terjamin kualitasnya. Penanganan produk yang tidak dilaksanakan sesuai pedoman keamanan pangan mengakibatkan potensi bahaya pada semua jenis produk pangan. Seperti pada jenis pangan olahan mi yang berbahan baku karbohidrat, produk tersebut rentan akan kerusakan kualitas pangan yang mengakibatkan produk pangan tersebut tidak aman untuk dikonsumsi.

PT. Jakarana Tama Food Industry (Factory) Bogor merupakan industri pangan olahan yang memproduksi mi instan. ISO dianggap sebagai standar manajemen yang dinilai paling fair dalam perdagangan dan penjaminan kualitas produk. PT. Jakarana Tama Food Industry (Factory) Bogor telah menerapkan ISO 22000:2005 sebagai standar Sistem Keamanan Pangan sejak tahun 2006, namun penerapannya masih belum efektif sepenuhnya. Berdasarkan hasil penilaian audit yang dilakukan secara internalyang dilakukan perusahaan, menunjukkan bahwa sebagian besar persyaratan atau klausul dalam ISO 22000 telah dipenuhi dan ada beberapa kriteria yang belum terpenuhi. Melalui pelaksanaan audit internal ini diharapkan mampu memastikan aktivitas keamanan pangan dilaksanakan secara efisien dan efektif. Tetapi kenyataannya, tindakan perbaikan dan pencegahan yang dilakukan perusahaan belum mampu mengurangi ketidaksesuaian produk noodle. Hal tersebut menjadi perhatian keamanan pangan, dengan masih adanya produk yang rusak maka akan menimbulkan bahaya biologis, fisik, dan kimia bagi konsumen.

Diharapkan perusahaan mampu meningkatkan kualitas dan keamanan produk kepada konsumen. Dalam mengantisipasi pesatnya kemajuan industri dan kompetisi yang dihadapi perusahaan pangan dan untuk mempertahankan eksistensinya, maka perlu adanya penelitian untuk mengetahui sejauh mana ISO 22000:2005 berpengaruh terhadap kualitas produk pada departemen noodle.

\section{MATERI DAN METODE}

Manajemen kualitas merupakan seluruh kegiatan yang terdiri dari merencanakan, mengorganisasi, mengendalikan dan evaluasi kualitas pada setiap peran manajemen dalam organisasi untuk mencapai kualitas suatu produk yang tinggi (Poerwanto, 2016). ISO 8402 mengartikan manajemen kualitas sebagai keseluruhan kegiatan manajemen (Gasperz, 1997), meliputi perencanaan, pengendalian, jaminan dan peningkatan kualitas.

\section{Sistem Manajemen Keamanan Pangan ISO 22000:2005}

Menurut Suardi (2001), ISO atau The International Organization for Standardization adalah standar dunia yang dibentuk untuk meningkatkan perdagangan global berkaitan dengan barang maupun jasa. ISO 22000 ialah pedoman standar internasional yang diperuntukkan untuk organisasi dalam rantai pangan atau mengenai permasalahan food safety yang dikeluarkan pada tahun 2005. Adapun persyaratan yang ditetapkan Sistem Keamanan Pangan ISO 22000:2005 dengan menggabungkan beberapa unsur kunci, seperti diantaranya komunikasi interaktif, manajemen sistem, program persyaratan dasar (PRP) dan prinsip HACCP (SNI ISO 22000:2009). 


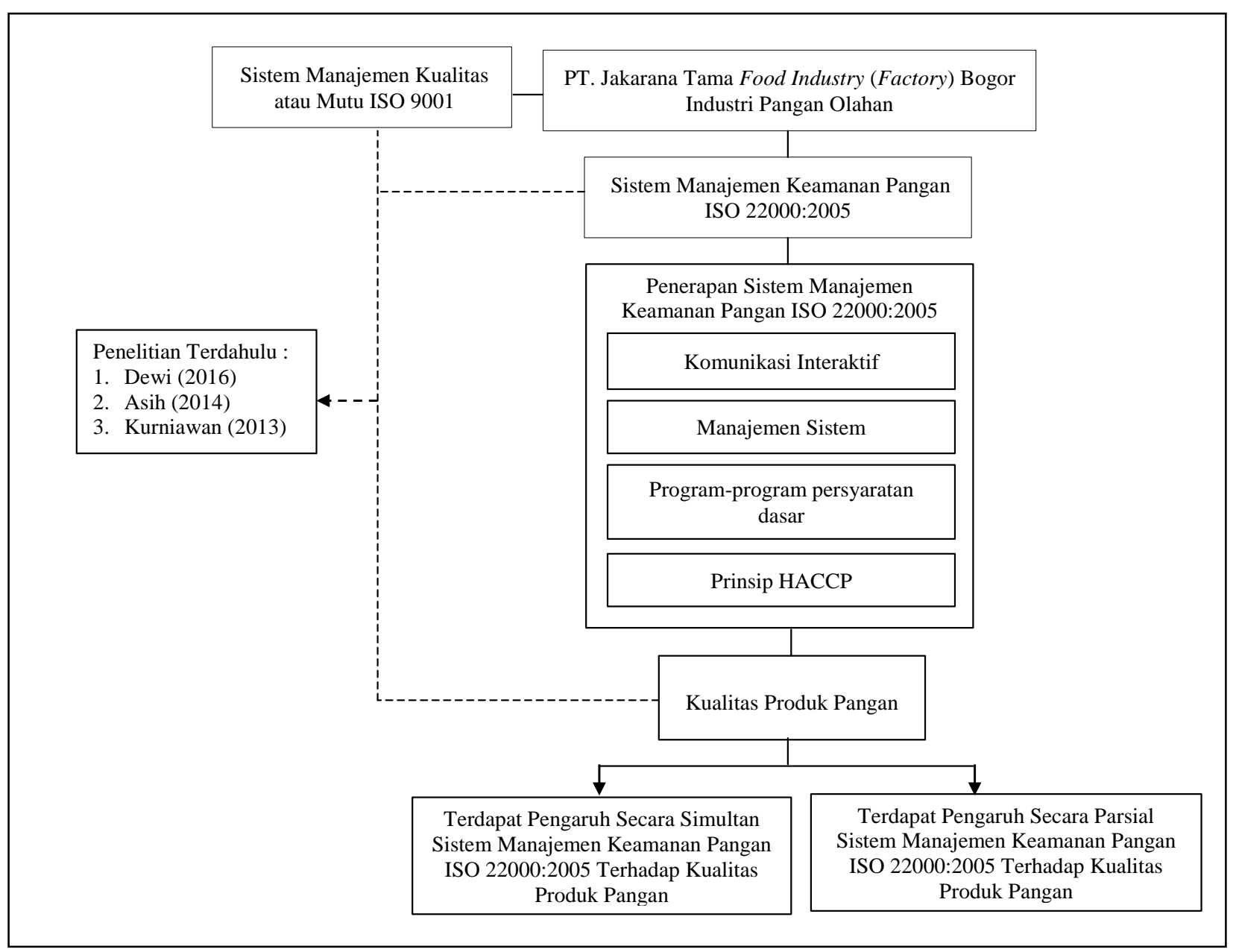

Gambar 1. Kerangka Pemikiran

\section{Kualitas Produk Pangan}

Konsep kualitas produk bersifat menyeluruh, baik kualitas bahan mentah, dalam proses maupun barang jadi. Sementara itu kualitas proses produksi meliputi semua hal yang berkaitan dengan proses pembentukan produk (produksi) pada perusahaan manufaktur atau proses penyediaan dan pelayanan jasa. Menurut Potter dan Hotchkiss (2012) menjelaskan bahwa kualitas produk pangan adalah sebagai suatu karakter pangan yang berkualitas dan dapat diterima oleh konsumen seperti bentuk, ukuran, warna, tekstur, rasa dan konsistensi. Sedangkan menurut Gaman, Sherrington dan Jones (2000), ada beberapa faktor yang dapat mempengaruhi kualitas produk pangan seperti diantaranya; warna, penampilan, porsi, bentuk, temperatur, tekstur, aroma, tingkat kematangan dan rasa.

\section{Metode Penelitian}

Metode penelitian dalam penelitian ini yaitu verifikatif dan deskriptif. Verifikatif adalah menjawab suatu permasalahan melalui konfirmasi tanpa adanya perbaikan (Mashuri, 2008), sementara itu penelitian deskriptif, menurut Umar (2008), adalah gambaran mengenai apa yang diteliti, lalu diolah dan dianalisis kemudian diambil kesimpulan. Objek penelitian ini adalah karyawan di departemen produksi noodle PT. Jakarana Tama Food Industry (Factory) Bogor. 
Tabel 1. Operasionalisasi Variabel

\begin{tabular}{|c|c|c|c|c|}
\hline Variabel & $\begin{array}{l}\text { Sub } \\
\text { Variabel }\end{array}$ & $\begin{array}{l}\text { Konsep Sub } \\
\text { Variabel }\end{array}$ & Indikator & $\begin{array}{l}\text { Skala } \\
\text { Ukur }\end{array}$ \\
\hline \multirow[t]{4}{*}{$\begin{array}{l}\text { Sistem } \\
\text { Manajemen } \\
\text { Keamanan } \\
\text { Pangan } \\
\text { ISO } \\
22000: 2005 \\
(X)\end{array}$} & $\begin{array}{l}\text { Komunikasi } \\
\text { interaktif } \\
\left(\mathrm{X}_{1}\right)\end{array}$ & $\begin{array}{l}\text { Komunikasi yang } \\
\text { dilakukan di } \\
\text { seluruh rantai } \\
\text { pangan yang } \\
\text { penting untuk } \\
\text { menetapkan } \\
\text { bahwa bahaya } \\
\text { keamanan pangan } \\
\text { dapat } \\
\text { diidentifikasi dan } \\
\text { dikendalikan (SNI } \\
\text { ISO 22000:2009) } \\
\end{array}$ & $\begin{array}{l}\text { 1. Kebijakan kualitas dan keamanan pangan produk } \\
\text { 2. Kompetensidanpelatihan } \\
\text { 3. Persyaratanpelanggandanpemasok }\end{array}$ & $\begin{array}{l}\text { Ordinal } \\
\text { Likert } \\
(1-5)\end{array}$ \\
\hline & $\begin{array}{l}\text { Manajemen } \\
\text { sistem }\left(\mathrm{X}_{2}\right)\end{array}$ & $\begin{array}{l}\text { Sistem keamanan } \\
\text { pangan yang } \\
\text { ditetapkan, } \\
\text { dioperasikan dan } \\
\text { dipadukan dalam } \\
\text { keseluruhan } \\
\text { kegiatan } \\
\text { manajemen } \\
\text { organisasi (SNI } \\
\text { ISO 22000:2009) } \\
\end{array}$ & $\begin{array}{l}\text { 1. Struktur organisasi } \\
\text { 2. Manual sistem } \\
\text { 3. Manajemen review } \\
\text { 4. Audit internal } \\
\text { 5. Evaluasi sistem }\end{array}$ & $\begin{array}{l}\text { Ordinal } \\
\text { Likert } \\
(1-5)\end{array}$ \\
\hline & $\begin{array}{l}\text { Program } \\
\text { persyaratan } \\
\text { dasar }\left(\mathrm{X}_{3}\right)\end{array}$ & $\begin{array}{l}\text { Kondisi dan } \\
\text { aktivitas dasar } \\
\text { yang dibutuhkan } \\
\text { untuk memelihara } \\
\text { lingkungan yang } \\
\text { higenis (PAS } \\
\text { 220:2008) }\end{array}$ & $\begin{array}{l}\text { 1. Konstruksidantataletakbangunan } \\
\text { 2. Tata letakruangdantempatkerja } \\
\text { 3. Utilitasudara, air danenergi } \\
\text { 4. Pembuangan limbah } \\
\text { 5. Kesesuaian, pembersihandanperawatanperalatan } \\
\text { 6. Pengelolaan material bahanbak } \\
\text { 7. Pengukuranterhadappencegahankontaminasisilang } \\
\text { 8. Pembersihandansanitasi } \\
\text { 9. Pengendalianhama } \\
\text { 10. Kebersihankaryawandanfasilitas } \\
\text { 11. Rework } \\
\text { 12. Penarikanproduk } \\
\text { 13. Pengudangan } \\
\text { 14. Informasiproduk } \\
\text { 15. Pengendalianakses }\end{array}$ & $\begin{array}{l}\text { Ordinal } \\
\text { Likert } \\
(1-5)\end{array}$ \\
\hline & $\begin{array}{l}\text { Prinsip } \\
\text { HACCP } \\
\left(\mathrm{X}_{4}\right)\end{array}$ & $\begin{array}{l}\text { Suatu sistem } \\
\text { mengidentifikasi, } \\
\text { evaluasi dan } \\
\text { mengendalikan } \\
\text { bahaya yang } \\
\text { signifikan bagi } \\
\text { keamanan pangan } \\
\text { (SNI CAC/RCP } \\
\text { 1:2011) } \\
\text { • }\end{array}$ & $\begin{array}{l}\text { 1. Analisa bahaya } \\
\text { 2. Identifikasi dan penentuantitik } \\
\text { 3. Penetapan batas kritis } \\
\text { 4. Penyusunan prosedur pemantauan dan } \\
\text { pengendalian } \\
\text { 5. Tindakan koreksi d perbaikan } \\
\text { 6. Verifikasi } \\
\text { 7. Rencana HACCP }\end{array}$ & $\begin{array}{l}\text { Ordinal } \\
\text { Likert } \\
(1 \text { an-5) }\end{array}$ \\
\hline $\begin{array}{l}\text { Kualitas } \\
\text { Produk } \\
\text { Pangan (Y) }\end{array}$ & & $\begin{array}{l}\text { Sebagai suatu } \\
\text { karakter pangan } \\
\text { yang berkualitas } \\
\text { dan dapat diterima } \\
\text { oleh konsumen } \\
\text { seperti bentuk, } \\
\text { ukuran, warna, } \\
\text { tekstur, rasa dan } \\
\text { konsistensi(Potter } \\
\text { dan Hotchkiss, } \\
\text { 2012) }\end{array}$ & $\begin{array}{l}\text { 1. Warna } \\
\text { 2.Penampilan } \\
\text { 3.Porsi } \\
\text { 4.Bentuk } \\
\text { 5. Temperatur } \\
\text { 6. Tekstur } \\
\text { 7. Aroma } \\
\text { 8. Tingkat kematangan } \\
\text { 9. Rasa }\end{array}$ & $\begin{array}{l}\text { Ordinal } \\
\text { Likert } \\
(1-5)\end{array}$ \\
\hline
\end{tabular}




\section{Populasi, Sampel dan Teknik Pengambilan Sampel}

Seluruh karyawan departemen produksi noodle PT. Jakarana Tama Food Industry (Factory) Bogor merupakan populasi dalam penelitian ini. Menurut Sugiyono (2013), sampel merupakan bagian dari populasi yang memiliki karakteristik tertentu. Dengan menggunakan rumus Slovin, penelitian ini mendapati ukuran sampel penelitian sebesar 99,47 orang, yang kemudian dibulatkan menjadi 100 orang.

\section{Operasionalisasi Variabel}

Variabel yang dianalisis terdiri dari variabel independen yaitu Sistem Manajemen Keamanan Pangan ISO 22000:2005 (X) yang memiliki sub variabel : komunikasi interaktif $\left(\mathrm{X}_{1}\right)$, manajemen sistem $\left(\mathrm{X}_{2}\right)$, program persyaratan dasar $\left(\mathrm{X}_{3}\right)$ dan prinsip HACCP $\left(\mathrm{X}_{4}\right)$. Sedangkan variabel dependen adalah kualitas produk pangan (Y). Secara rinci, penjabaran dari variabel penelitian dapat dilihat pada tabel $1 \mathrm{di}$ atas.

\section{Jenis dan Sumber Data}

Perolehan data dikumpulkan untuk keperluan penelitian ini berupa data primer dan data sekunder. Prosedur pengumpulan data dilakukan dengan studi kepustakaan dan studi lapangan (wawancara, pengamatan dan kuesioner).

Awalnya data diuji sebelum akhirnya diolah dan dianalisis dengan tujuan mengetahui keyakinan responden dalam menjawab kuesioner yaitu uji validitas, reliabilitas dan asumsi klasik. Uji validitas berfungsi mengukur pernyataan di dalam kuesioner, semua indikator pada kuesioner dikatakan memiliki kebenaran jika memiliki koefisien korelasi product moment sebesar 0,30 $(\geq 0,30)$ (Sugiyono, 2013). Instrumen itu, selain penelitian harus valid, juga harus dapat dipercaya (reliabel), seluruh instrumen reliable dan memiliki angka Cronbanch Alpha sebesar 0,6 ( $\geq 0,6)$ (Sugiyono, 2013). Sedangkan uji asumsi klasik yakni uji statistika yang dipenuhi pada analisis regresi linear berganda yang berbasis Ordinary Least Square (OLS).

\section{Metode Analisis Data}

Perolehan data yang telah dikumpulkan akan dianalisis menggunakan uji statistik secara verifikatif dan deskriptif. Adapun persamaan umum regresi linear berganda, yaitu :

$$
\mathrm{Y}=\alpha+\beta_{1} \mathrm{X}_{1}+\beta_{2} \mathrm{X}_{2}+\beta_{3} \mathrm{X}_{3}+\beta_{4} \mathrm{X}_{4}+\varepsilon
$$

Keterangan :

$\mathrm{Y}=$ Kualitas produk pangan

$\mathrm{X}=$ Sistem Manajemen Keamanan Pangan

$\alpha=$ Konstanta

$\beta=$ Angka arah atau koefisien regresi, yang menunjukkan angka peningkatan ataupun penurunan variabel dependen yang didasarkan pada perubahan variabel independen

$\mathrm{X}_{1}=$ Komunikasi interaktif

$\mathrm{X}_{2}=$ Manajemen sistem

$\mathrm{X}_{3}=$ Program persyaratan dasar

$\mathrm{X}_{4}=$ Prinsip HACCP

$\varepsilon \quad=$ Faktor lain yang tidak diteliti

Untuk menguji hipotesis penelitian, digunakan uji statistik dengan model penelitian sebagai berikut:

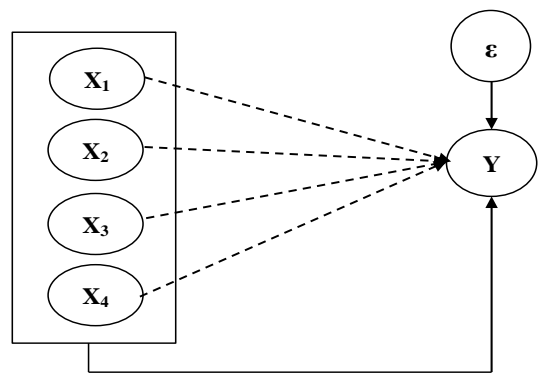

Gambar 2. Hubungan Antara Variabel Penelitian

\section{HASIL DAN PEMBAHASAN}

PT. Jakarana Tama Food Industry (Factory) Bogor berada di Jl. Raya Ciawi-Sukabumi km 2,5 No. 88, Ciawi Bogor, memiliki luas area pabrik 6 hektar dan luas bangunan 2,5 hektar. Pabrik yang memproduksi mi instan dengan merek "Gaga" ini telah mendapatkan sertifikat HALAL dengan nomor 00090012840700 dan juga telah mendapatkan sertifikat HACCP dengan nomor LTIPB-SHACCP-018-2006. 


\section{Karakteristik Responden}

Responden sebagai sampel pada penelitian ini berjumlah 100 orang karyawan departemen noodle PT. Jakarana Tama Food Industry (Factory) Bogor. Sementara itu identitas karyawan dijelaskan menurut jenis kelamin, usia, pendidikan, jabatan pekerjaan dan usia bekerja pada PT. Jakarana Tama Food Industry (Factory)Bogor.Jadi dapatdikatakan bahwa karyawan rata-rata berjenis kelamin perempuan, berusia lebih dari 36 tahun dengan jabatan pekerjaan sebagai helper, pendidikan terakhir SMA/SMK sederajat dan kebanyakan karyawan telah bekerja lebih dari 15 tahun. Hasil rekapitulasi dari jawaban karyawan mengenai pelaksanaan ISO 22000:2005 dan kualitas produk pangan pada departemen produksi noodle, yaitu sebagai berikut:

Tabel 2. Rekapitulasi Tanggapan Responden

\begin{tabular}{lcl}
\hline Variabel & Mean & \multicolumn{1}{c}{ Ket } \\
\hline Komunikasi Interaktif $\left(\mathrm{X}_{1}\right)$ & 4,32 & Sangat Baik \\
Manajemen Sistem $\left(\mathrm{X}_{2}\right)$ & 4,08 & Baik \\
Program Persyaratan & 4,27 & Sangat Baik \\
$\begin{array}{l}\text { Dasar }\left(\mathrm{X}_{3}\right) \\
\text { Prinsip HACCP }\left(\mathrm{X}_{4}\right)\end{array}$ & 4,19 & Baik \\
$\begin{array}{l}\text { Kualitas Produk Pangan } \\
\text { (Y) }\end{array}$ & 4,43 & Sangat Baik \\
\hline \multicolumn{1}{c}{ Rata-rata } & 4,25 & Sangat Baik \\
\hline
\end{tabular}

Berdasarkan tabel tersebut maka rekapitulasi rata-rata penerapan ISO 22000:2005 dan kualitas produk pangan di departemen produksi noodle PT. Jakarana Tama Food Industry (Factory) Bogor adalah sebesar 4,25, dengan nilai tertinggi yaitu 4,43 kualitas produk pangan dan nilai terendah 4,08 yaitu manajemen sistem.

\section{Hasil Estimasi Persamaan Regresi}

Adapun persamaan tersebut menunjukkan pengaruh Sistem Manajemen Keamanan Pangan ISO 22000:2005 terhadap produk pangan pada departemen produksi noodle PT. Jakarana Tama Food Industry (Factory) Bogor. Adapun hasil perhitungan dengan menggunakan analisis regresi linear berganda yaitu :

$Y=0,86-0,027 X 1-0,028 X 2+0,573 X 3+0,109 X 4+\varepsilon$
Persamaan tersebut menunjukkan bahwa Sistem Manajemen Keamanan Pangan ISO 22000:2005 berpengaruh positif terhadap kualitas produk pangan pada departemen produksi noodle PT. Jakarana Tama Food Industry (Factory) Bogor. Hubungan Sistem Manajemen Keamanan Pangan ISO 22000:2005 dengan kualitas produk pangan menunjukkan angka korelasi 0,774, hal tersebut menggambarkan bahwa semakin baik penerapan Sistem Manajemen Keamanan Pangan ISO 22000:2005 maka kualitas produk pangan pada departemen produksi noodle PT. Jakarana Tama Food Industry (Factory) Bogor juga akan meningkat.

Besarnya Sistem Keamanan Pangan ISO 22000:2005 berpengaruh terhadap kualitas produk pangan secara simultan dilihat dari $R$ Square sebesar 0,599 atau 59,9\%. Besarnya persentase sumbangan pengaruh variabel Sistem Manajemen Keamanan Pangan ISO 22000:2005 (X) terhadap kualitas produk pangan pada departemen produksi noodle PT. Jakarana Tama Food Industry (Factory) Bogor (Y) sebesar $59,9 \%$. Sedangkan sisanya $40,1 \%$ dipengaruhi oleh faktor lain seperti pasar, tujuan organisasi, testing produk, desain produk, proses produksi, kualitas input dan umpan balik konsumen (Yamit, 2005).

\section{Pengujian Koefisisen Regresi Secara Simultan (Uji F)}

Pengaruh Sistem Manajemen Keamanan Pangan ISO 22000:2005 (X) secara simultan terhadap kualitas produk pangan pada departemen produksi noodle PT. Jakarana Tama Food Industry (Factory) Bogor (Y) secara statistik akan di uji hipotesisnya yaitu :

$\mathrm{H}_{0}: \beta \mathrm{i} \leq 0$ : tidak terdapat pengaruh secara simultan penerapan Sistem Manajemen Keamanan Pangan ISO 22000:2005 (X) terhadap kualitas produk pangan departemen noodle (Y).

$\mathrm{H} \alpha: \beta \mathrm{i}>0:$ terdapat pengaruh secara simultan penerapan Sistem Manajemen Keamanan Pangan ISO 22000:2005 (X) terhadap 
kualitas produk pangan departemen Noodle (Y).

Hasil uji-F yang diperoleh bahwa nilai $F_{\text {hitung }}$ sebesar 35,494 dan nilai $F_{\text {tabel }}$ untuk $\alpha=0,05$ dengan derajat kebebasan $\mathrm{V}_{1}=5-1=4$ dan $\mathrm{V}_{2}=$ $100-3-1=95$ sebesar 2,49 berarti $F_{\text {hitung }}$ lebih besar dari $\mathrm{F}_{\text {tabel }}(35,494>2,49)$, berarti dapat dikatakan bahwa Ho ditolak dan Ha diterima artinya dengan tingkat kepercayaan 95\% variabel independen Sistem Manajemen Keamanan Pangan ISO 22000:2005 (X) berpengaruh positif dan signifikan secara simultan (bersama-sama) terhadap kualitas produk pangan pada departemen produksi noodle PT. Jakarana Tama Food Industry (Factory) Bogor (Y).

\section{Pengujian Koefisisen Regresi Secara Parsial (Uji-t)}

Hasil uji-t secara parsial setiap variabel independen komunikasi interaktif, manajemen sistem, program persyaratan dasar (PRP) dan prinsip HACCP terhadap kualitas produk pangan yaitu :

1. Pengaruh Penerapan Komunikasi Interaktif $\left(\mathrm{X}_{1}\right)$ terhadap Kualitas Produk Pangan pada Departemen Produksi Noodle PT. Jakarana Tama Food Industry (Factory) Bogor (Y).

Secara statistik akan di uji hipotesisnya yaitu :

$\mathrm{H}_{01}: \beta_{1} \leq 0$ : Tidak terdapat pengaruh penerapan komunikasi interaktif $\left(\mathrm{X}_{1}\right)$ terhadap kualitas produk pangan pada departemen noodle PT. Jakarana Tama Food Industry (Factory) Bogor (Y).

$\begin{aligned} \mathrm{H} \alpha_{1}: \beta_{1}>0 & : \text { Terdapat } \\ & \text { penerapan } \quad \text { komuaruh } \\ & \text { interaktif }\left(\mathrm{X}_{1}\right) \text { terhadap } \\ & \text { kualitas produk pangan } \\ & \text { pada departemen noodle } \\ & \text { PT. Jakarana Tama Food }\end{aligned}$
Industry (Factory) Bogor (Y).

Hasil perhitungan diperoleh $t_{\text {hitung }}$ pada komunikasi interaktif $\left(\mathrm{X}_{1}\right)$ sebesar -0.080 dan nilai $t_{\text {tabel }}$ untuk $\alpha=0,05$ dengan derajat kebebasan sebesar 1,664 berarti $(-0.080<1,664)$. Maka H0 diterima dan $\mathrm{H} \alpha$ ditolak, artinya penerapan komunikasi interaktif (X1) tidak mempunyai pengaruh positif terhadap kualitas produk pangan pada departemen noodle PT. Jakarana Tama Food Industry (Factory) Bogor (Y). Seperti dikemukakan oleh Samuel dan Zulkarnain (2011), tidak berperan nyatanya komunikasi interaktif disebabkan oleh satu diantaranya adalah ketidakpuasan karyawan terhadap sistem komunikasi. Lebih lanjutlagi kurangnya kerja sama antar bagian dalam melakukan penyelesaian ataupun perbaikan pelaksanaan ISO 22000, serta kurangnya komunikasi antar bagian menyebabkan perubahan secara internal yang memiliki dampak pada keamanan pangan lambat atau tidak dapat terinformasikan dengan baik keseluruh bagian. Peranan pihak manajemen sangat dibutuhkan untuk dapat menunjang pelaksanaan ISO 22000, peranan manajemen contohnya dari bentuk komitmen manajemen dalam mendukung penerapan ISO 22000 (Asih, 2014),

2. Pengaruh Penerapan Manajemen Sistem $\left(\mathrm{X}_{2}\right)$ terhadap Kualitas Produk Pangan pada Departemen Produksi Noodle PT. Jakarana Tama Food Industry (Factory) Bogor (Y).

Secara statistik akan di uji hipotesisnya yaitu :

$$
\begin{array}{r}
\mathrm{H}_{01}: \beta_{1} \leq 0: \text { Tidak terdapat pengaruh } \\
\text { penerapan manajemen } \\
\text { sistem }\left(\mathrm{X}_{2}\right) \text { terhadap } \\
\text { kualitas produk pangan } \\
\text { pada departemen noodle } \\
\text { PT. Jakarana Tama Food }
\end{array}
$$




\section{Industry (Factory) Bogor (Y).
$\mathrm{H} \alpha_{1}: \beta_{1}>0$ : Terdapat pengaruh penerapan manajemen sistem $\quad\left(\mathrm{X}_{2}\right)$ terhadap kualitas produk pangan pada departemen noodle PT. Jakarana Tama Food Industry (Factory) Bogor (Y).

Hasil perhitungan diperoleh $\mathrm{t}_{\text {hitung }}$ pada manajemen sistem $\left(\mathrm{X}_{2}\right)$ sebesar-0.149 dan nilai $t_{\text {tabel }}$ untuk $\alpha=0,05$ dengan derajat kebebasan sebesar 1,664 berarti $(-0.149<1,664)$. Maka H0 diterima dan $\mathrm{H} \alpha$ ditolak, artinya penerapan manajemen sistem $\left(\mathrm{X}_{2}\right)$ tidak mempunyai pengaruh positif terhadap kualitas produk pangan pada departemen noodle PT. Jakarana Tama Food Industry (Factory) Bogor (Y). Menurut Asih (2014), evaluasi sistem terkait berjalannya sistem dalam manajemen yang seharusnya dilakukan secara keseluruhan namun aktualnya tidak dilakukan maka akanberakibat keberadaan sistem manajemen tersebut tidak mempengaruhi kualitas produk.

3. Pengaruh Penerapan Program Persyaratan Dasar $\left(\mathrm{X}_{3}\right)$ terhadap Kualitas Produk Pangan pada Departemen Produksi Noodle PT. Jakarana Tama Food Industry (Factory) Bogor (Y). Secara statistik akan di uji hipotesisnya yaitu:
$\mathrm{H}_{01}: \beta_{1} \leq 0$ : Tidak terdapat pengaruh penerapan program persyaratan dasar $\left(\mathrm{X}_{3}\right)$ terhadap kualitas produk pangan pada departemen noodle PT. Jakarana Tama Food Industry (Factory) Bogor (Y).

$$
\mathrm{H} \alpha_{1}: \beta_{1}>0: \begin{array}{r}
\text { Terdapat } \\
\text { penerapan }
\end{array} \quad \begin{array}{r}
\text { pengaruh } \\
\text { program }
\end{array}
$$

persyaratan dasar $\left(\mathrm{X}_{3}\right)$ terhadap kualitas produk pangan pada departemen noodle PT. Jakarana Tama Food Industry (Factory) Bogor (Y).

Hasil perhitungan diperoleh $\mathrm{t}_{\text {hitung }}$ pada program persyaratan dasar $\left(\mathrm{X}_{3}\right)$ sebesar 6.931 dan nilai $t_{\text {tabel }}$ untuk $\alpha=0,05$ dengan derajat kebebasan sebesar 1,664 berarti (6.931> 1,664). Maka $\mathrm{H}_{0}$ ditolak dan $\mathrm{H} \alpha$ diterima, artinya penerapan program persyaratan dasar $\left(\mathrm{X}_{3}\right)$ mempunyai pengaruh positif terhadap kualitas produk panganpada departemen noodle PT. Jakarana Tama Food Industry (Factory) Bogor (Y). Hal ini seperti diungkapkan oleh Faergemand dan Jespersen (2004), penerapan program persyaratan dasar efektif akan dapat memaksimalkan kualitas produk serta kinerja karyawan

4. Pengaruh Penerapan Prinsip HACCP $\left(\mathrm{X}_{4}\right)$ terhadap Kualitas Produk Pangan pada Departemen Produksi Noodle PT. Jakarana Tama Food Industry (Factory) Bogor (Y). Secara statistik akan di uji hipotesisnya yaitu :

$\mathrm{H}_{04}: \beta_{4} \leq 0$ : Tidak terdapat pengaruh penerapan prinsip HACCP $\left(\mathrm{X}_{4}\right)$ terhadap kualitas produk pangan pada departemen noodle PT. Jakarana Tama Food Industry (Factory) Bogor (Y).

$\begin{aligned} \mathrm{H \alpha}_{4}: \beta_{4}>0: & \text { Terdapat pengaruh penera- } \\ & \text { pan prinsip HACCP }\left(\mathrm{X}_{4}\right) \\ & \text { terhadap kualitas produk } \\ & \text { pangan pada departemen } \\ & \text { noodle PT. Jakarana Tama } \\ & \text { Food Industry (Factory) } \\ & \text { Bogor }(\mathrm{Y}) .\end{aligned}$

Hasil perhitungan diperoleh $t_{\text {hitung }}$ pada prinsip HACCP $\left(\mathrm{X}_{4}\right)$ sebesar 0,713dan 
nilai $t_{\text {tabel }}$ untuk $\alpha=0,05$ dengan derajat kebebasan sebesar 1,664 berarti $(0,713<$ 1,664). Maka $\mathrm{H}_{0}$ diterima dan $\mathrm{H \alpha}$ ditolak, artinya penerapan prinsip $\mathrm{HACCP}\left(\mathrm{X}_{4}\right)$ tidak mempunyai pengaruh positif terhadap kualitas produk panganpada departemen noodle PT. Jakarana Tama Food Industry (Factory) Bogor (Y). Hambatan utama untuk menerapkan prinsip HACCP adalah kesalahan waktu dan suhu, titik kontrol kritis, dokumentasi yang buruk dan monitoring tidak konsisten berakibat padapenurunnya kualitas produk pangan (Base, et al., 2006; Herath dan Henson, 2010; Hielm et al., 2006).

\section{KESIMPULAN DAN IMPLIKASI}

Berdasarkan kesimpulan dari penelitian dan pembahasan yaitu : 1) tanggapan karyawan pada departemen produksi noodle terhadap penerapan komunikasi interaktif, program persyaratan dasar dan kualitas produk pangan sudah sangat baik, sedangkan penerapan manajemen sistem dan prinsip HACCP sudah dilakukan dengan baik. 2) Uji F pada pelaksanaan ISO 22000:2005 secara simultan mempengaruhi kualitas produk pangan pada departemen produksi noodle PT. Jakarana Tama Food Industry (Factory) Bogor. 3) Uji-t, program persyaratan dasar (PRP) terhadap kualitas produk pangan pada departemen produksi noodle. Sedangkan komunikasi interaktif, manajemen sistem dan prinsip HACCP tidak mempengaruhi kualitas produk pada departemen produksi noodle.

Adapun saran yang diberikan adalah 1) Pelaksanaan ISO 22000:2005 pada departemen noodle PT. Jakarana Tama Food Industry (Factory) Bogor secara simultan sudah berjalan dengan baik, harus dipertahankan dan terus ditingkatkan karena akan berpengaruh terhadap kualitas produk pangan. 2) Perlu adanya peningkatan sosialisasi ISO 22000 terutama mengenai manajemen sistem perusahaan, prosedur HACCP serta peningkatan komunikasi baik internal maupun eksternal yang diharapkan mampu menunjang pelaksanaan ISO 22000 secara konsisten dan dapat berjalan dengan efektif untuk dapat memperoleh produk yang berkualitas serta aman dikonsumsi.

\section{DAFTAR PUSTAKA}

Asih, Ratna Dewi, 2014, Kajian Penerapan Sistem Manajemen Keamanan Pangan ISO FSSC 22000 di PT. Sariwangi A.E.A Divisi Internasional, Skripsi Sarjana, Fakultas Ekonomi dan Manajemen Institut Pertanian Bogor, Bogor.

Codex Alimentarius Commission, (2003). Recommended International Code of Practice General Principles of Food Hygiene. CAC/RCP 1-1969, Rev. 4,http://www.codexalimentarius.net .diakses tanggal 10 Oktober 2016.

Dewi, Dewa Ayu Putu Candra, 2016, Pengaruh

Sistem Manajemen Keamanan

Pangan ISO 22000:2005 Terhadap Kinerja Perusahaan (PT. Aerofood ACS Denpasar), Jurnal Beta (Biosistem dan Teknik Pertanian), Fakultas Teknologi Pertanian Universitas Udayana, Bali.

Faergemand, J. dan D Jespersen., D. 2004. ISO 22000 to Ensure Integrity of Food Supply Chain. https://www.iso.org/iso/tool_5-04.pdf. diakses tanggal: 28 Mei 2017.

Gaman, Sherrington dan Jones,2000.The Science of Food. Mass: ButterworthHeinemann. Boston.

Gasperz, Vincent, 1997.Manajemen Kualitas, Penerapan Konsep-konsep Kualitas Dalam Manajemen Bisnis Total. PT Gramedia Pustaka Utama. Jakarta.

Gemina, Dwi, 2012, Pengaruh Program Corporate Social Responsibility PT. Aneka Tambang Terhadap Peningkatan Taraf Hidup Masyarakat Kecamatan Nanggung Kabupaten Bogor, Jurnal Penelitian, Fakultas Ekonomi Universitas Djuanda, Bogor.

Herath, D. dan S. Henson, 2010, Barriers to HACCP Implementation: Evidence from the Food Processing Sector in 
Ontario Canada Agribusiness, Vol. 26 No. 2, pp. 265-279. diakses tanggal: 28 Mei 2017.

Knight, J.B dan L.H Kotschevar, 2000.Quantity

Food Production and Planning. John Willey and Sons.

Kotto, Eddy S S, 2012, “ Panduan Lengkap Sistem Manajemen Keamanan Pangan",

BAB IV ISO-TS 22002-1/PAS 220:2008, Jakarta: halaman 185.

Kurniawan, Arip, 2013, Pengaruh Penerapan

Standar ISO 9001 Terhadap Kualitas Produk (Studi Kasus pada PT Trisula Textile Industries), Skripsi Sarjana, Fakultas Ekonomi Universitas Pendidikan Indonesia, Bandung.http://repository.upi.edu/4412/1 /S PEM 0707640 Title.pdf._diakses tanggal 09 Oktober 2016.

Margaretha, F.S dan Edwin J, 2012, Analisa

Pengaruh Food Quality and Brand Image Terhadap Keputusan Pembelian Roti Kecik Toko Roti Ganep's di Kota Solo. Solo:Jurnal Manajemen Pemasaran, Vol. 1, No. 1. Mashuri, 2008.Penelitian Verifikatif. Edisi Pertama. Penerbit Andi.Yogyakarta.

Papademas, Photis dan Thomas Bintsis, 2010, Food Safety Management Systems (FSMS) in The Dairy Industry, Jurnal Penelitian Departemen Ilmu Pertanian Biologi dan Ilmu Pangan, Universitas Teknologi Limassol, Cyprus.http://dlx.booksc.org/09600000/1 ibgen.scimag 0961200009612999.zip/browse/10.1111/ j.1471-0307.2010.00620.x.pdf. diakses tanggal 26 Mei 2017.

Poerwanto, G Hendra, 2016, Pengertian, Sejarah dan Arti Penting Manajemen Kualitas, Artikel, Program Studi Manajemen Universitas Sanata Dharma, Depok.

https://sites.google.com/site/kelolakualit as/Manajemen-Kualitas . diakses tanggal 09 Februari 2017.
Potter, N.N dan J.H Hotchkiss. 2012. Food Science (5 th Edition). Chapman dan Hall. New York.

Premysis Consulting, 2013.PAS 220:2008 Prerequisite Programmes On Food Safety For Food Manufacturing. Premysis Consulting. Jakarta.

Segovia, Isabel Fernandez dan Ana Perez Liacer, 2014, Implementation of a Food Safety Management System According to ISO 22000 in The Food Supplement Industry: A Case Study, Jurnal Penelitian Departemen Teknologi Universitas Politecrica de Valencia, Spain.

http://dlx.booksc.org/23100000/libgen.sc imag231520023152999.zip/browse /10.1016/j.foodcont.2014.02.042.pdf.dia kses tanggal 26 Mei 2017.

Semuel, Hatane dan Joni Zulkarnain (2013), Pengaruh Sistem Manajemen Mutu ISO terhadap Kinerja Karyawan Melalui Budaya Kualitas Perusahaan (Studi Kasus PT. Otsuka Indonesia Malang, Laporan Penelitian, Fakultas Ekonomi Universitas Kristen Petra, Surabaya.http://puslit2.petra.ac.id/gudan gpaper/files/2053.pdf. diakses tanggal 09 Oktober 2016.

Standar Nasional Indonesia No. CAC/RCP 11969, Rev. 4-2003, IDT, Tentang Rekomendasi Nasional, Kode PraktisPrinsip Umum Higiene Pangan(SNI CAC/RCP 1:2011), Badan Standarisasi Nasional Indonesia, Jakarta.

Standar Nasional Indonesia No. ISO 22000:2005, IDT, Tentang Sistem Manajemen Keamanan PanganPersyaratan untuk Organisasi dalam Rantai Pangan (SNI ISO 22000:2009), Badan Standarisasi Nasional Indonesia, Jakarta.

Suardi, R. 2001.Sistem Manajemen Mutu ISO 9000:2000 : Penerapan untuk Mencapai TQM.PPM. Jakarta.

Sugiyono .2013. Metode Penelitian Kuantitatif, Kualitatif dan Kombinasi (Mixed 
Methods). Cetakan Ketiga. Alfabeta. West, Wood, dan Harger,1966.Food Service in Jakarta.

Umar, Husein. 2008. Metode Riset Komunikasi Institution. Publisher: Willey. New York.

Organisasi. Gramedia Pustaka Utama. Jakarta.

Yamit, Zulian, 2013. Manajemen Kualitas Produk dan Jasa. Cetakan Keenam. Kampus Fakultas Ekonomi Universitas Islam Indonesia. Penerbit Ekonisia. Yogyakarta. 